\title{
Impact of Endemic Calciphilous Flora of the Central Russian Upland on the Nitrogen Regime of Carbonate Soils and Sub-Soils
}

\author{
Vladimir I. Cherniavskih ${ }^{1}$, Elena V. Dumacheva ${ }^{2}$, Fedor N. Lisetskiii ${ }^{3 *}$, Irina V. Batlutskaya ${ }^{4}$ \\ and Valentina B. Tsugkieva ${ }^{5}$ \\ ${ }^{1}$ Botanical Garden, Belgorod State National Research University, Belgorod, 308015, Russia \\ ${ }^{2}$ Department of Biology, Belgorod State National Research University, Belgorod, 308015, Russia \\ ${ }^{3}$ Federal and Regional Centre for Aerospace and Surface Monitoring of the Objects and Natural Resources, \\ Belgorod State National Research University, Belgorod 308015, Russia \\ ${ }^{4}$ Department of Biotechnology and Microbiology, Belgorod State National Research University, Belgorod, \\ 308015, Russia \\ ${ }^{5}$ Department of Production Technology, Storage and Processing of Crop Products, Gorsky State Agrarian \\ University, Vladikavkaz, 362040, the Republic of North Ossetia-Alania, Russia
}

\begin{abstract}
Unique plant communities that are complementary to the cretaceous substrate tend to be formed on the cretaceous outcrops of southern European Russia. They are characterized by a wide spread of calciphilous species of higher plants, including endemic ones. Under these conditions, stable plant aggregations are created by the species that are able to populate substrates being toxic to most plants. The study was conducted in order to examine the nitrogen status of soils and sub-soils under endemic calciphilous species: Matthiola fragrans Bunge, Hyssopus cretaceus Dubjan. and Andorsace koso-poljanskii Ovcz. The research tasks included a comparative analysis of the dynamic changes in the content of organic matter carbon, total nitrogen, easily hydrolysable nitrogen, nitrate nitrogen, and nitrification capacity of soils and sub-soils in the course of vital processes of the species under study. It has been found that during the ten-year period of the experiment for $M$. fragrans Bunge, $H$. cretaceus Dubjan significantly increases the number of particles of $<1 \mathrm{~mm}$
\end{abstract}

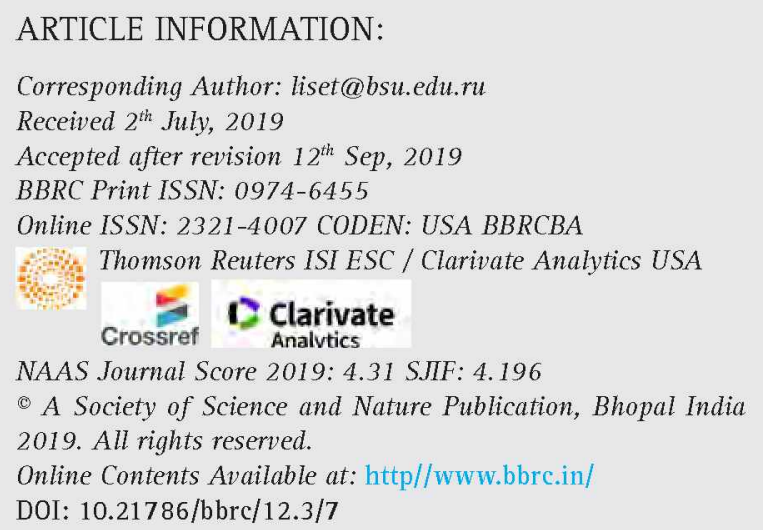


in size. Over the 10 -year period, their share has increased by 186.6 and $131.4 \%$ in relative terms respectively. There are two parallel on-going processes observed: increasing the number of fine particles and changes in the content of different forms of nitrogen in the substrate. We have noted positive dynamics in the accumulation of easily hydrolysable nitrogen and nitrate nitrogen under the species that can develop at the early stages of cretaceous outcrops overgrowth. It is most noticeable under $M$. fragrans Bunge, $H$. cretaceus Dubjan. We have found that $A$. koso-poljanskii Ovcz. can have a preserving effect on the substrate, which becomes obvious through its more stable nitrification capacity in time.

KEY WORDS: ENDEMTC PLANT, CARBONATE SOILS, TOTAL NITROGEN, TOTAL CARBON, SOIL BIOLOGICAL ACTIVITY

\section{INTRODUCTION}

Landscape systems with a wide spread of soil-forming rock exposures are typical for different regions of the world. They are formed due to particular terrain features, climatic conditions, and natural erosion processes, as well as under anthropogenic influence, and have distinctive vegetation. Carbonate outcrops hold a unique position among them (Scholle et.al. 1983, Cowling and Hilton-Taylor 1994, Robinson and Hermanutz 2015). The composition and productivity specific of plant associations is largely due to the diversity of habitat conditions, including lithological composition of rocks and pedodiversity (Lisetskii 2012, Lisetskii et al. 2016, Gusev et al. 2017). Distinctive plant communities with widespread calciphilous species of higher plants are formed on substrates made of chalk and marl. Some species that are able to populate carbonate substrates, while producing toxic effect on most plants, form stable plant groups and effectively absorb macronutrients and trace elements, which includes consortive relations with soil microorganisms (Lousley 1969, Maschinski 2004, Baskauf and Burke 2009, Kurkina et al. 2015, Abe et al. 2018, Dorofeeva et al. 2018).

The role of the anthropogenic factor became apparent 450,000 years ago and resulted in changing grassy steppes (Lisetskii 1992). For forest steppe, the human influence has also contributed to the reduced forest area over the last 300 years (Ukrainskij et al. 2017) and it is currently translated into one-way changes in the regional climate (Lisetskii 2007). In recent decades, the share of arable land has decreased, more fallow lands have appeared, and the rate of erosion has decreased. Ravine systems with outcrops of carbonate parent rocks (residual chalk deposits and marl) are widespread in the geographical coverage of the landscapes of the southern part of European Russia (Gorbunov and Bykovskaya 2012, Dumacheva et al. 2015). It is noteworthy that an important feature of carbonate outcrops is that they are formed on a mobile substrate, which is due to the constant influence of water run-off and weathering processes. The substrate mobility makes it difficult for plant matter and fine-grained soil to be accumulated, which in its turn causes a lack of humus. Chalk substrates are characterized by low average daily temperature fluctua- tions and lower average annual surface temperature in comparison with zonal soils. The flora of such territories is characterized by a high degree of endemism and uniqueness (Golitsyn 1956, Abramova 1973, Khadeeva et al. 2011).

Earlier (Degtyar and Chernyavskih 2006) they estimated the chemical content (active form P, K, Ca, Mg, S) of communities with prevailing rare and endemic species in the substrate surrounding rhizosphere and in the aboveground vegetation mass for the south the Central Russian Upland. It is established that endemic highly specialized calciphilous species - $M$. fragrans Bunge, $H$. cretaceus Dubjan, Scorophularia cretacea Fisch. ex Spreng have the strongest environment-transforming role on any substrate that has not yet been affected by biogenic processes. The process of further soil formation is associated with the development of communities where prevail A. koso-poljanskii Ovcz. (Degtyar and Chernyavskih 2006).

It becomes important to study the nitrogen status in soils and sub-soils, as well as its dynamics in relation to specific carbonate substrates. It is of interest to have studies on nitrogen-related nutrients consumption and on increased bioresource territory potential by preserving the existing populations and possible introduction of new species (Altay et.al. 2016, Rodríguez-Celma et.al. 2016).This study was conducted to examine the nitrogen status in the substrates occupied by three calciphilous species: $M$. fragrans Bunge, $H$. cretaceus Dubjan. and $A$. koso-poljanskii Ovcz. The scope of the study included a comparative analysis of the dynamic changes in the content of organic matter carbon, total nitrogen, easily hydrolysable nitrogen, nitrate nitrogen, and substrate nitrification capacity in the course of vital processes of three calciphilous species within the ten-year experiment.

\section{MATERIAL AND METHODS}

Study area: The research covered the southwestern macro slope of the Central Russian Upland, where landscapes with carbonate soils and cretaceous outcrops are widely spread within the Belgorod region (Russian Federation). This region has a high level of agricultural and 
industrial development and it is characterized by apparent and soil erosion. Against this background, the region has a high diversity of vegetation and a high degree of endemism, which is related to the extra-glacial territory position during the last glaciation. The climatic conditions of the region are diverse. With the sunshine duration of about 1800 hours, the amount of solar radiation is $4000 \mathrm{MJ} / \mathrm{m}^{2}$ on the average. The mean annual temperature ranges from $5.4^{\circ} \mathrm{C}$ to $6.7^{\circ} \mathrm{C}$. The average summer temperature increases from $18.4^{\circ} \mathrm{C}$ to $19.6^{\circ} \mathrm{C}$ towards the southeast. The average winter temperature drops from $-6.5^{\circ} \mathrm{C}$ in the south to $-8.0^{\circ} \mathrm{C}$ in the north. The snow cover period lasts from 100 (SE) to 120 days (S). The average annual rainfall ranges from $530-550 \mathrm{~mm}$ in the northwest to $465-490 \mathrm{~mm}$ in the southeast. In some years, the amount of precipitation can increase up to $700-800 \mathrm{~mm}$, and other reduced to $300 \mathrm{~mm}$. The vegetation period accounts for about $70 \%$ of the precipitation. The studies were aimed at the local populations $M$. fragrans Bunge, $H$. cretaceus Dubjan, A. koso-poljanskii Ovcz., that were identified in the model area with cretaceous outcrops near Alekseevka, Belgorod region (50'38'50' $\mathrm{N}$, $\left.37^{\circ} 49^{\prime} 35^{\prime \prime} \mathrm{E}\right)$. For this area, the average duration of the period with $\Sigma t>10^{\circ} \mathrm{C}$ is 157 days, the average annual rainfall is $486 \mathrm{~mm}$, the average annual air temperature is $+6.2^{\circ} \mathrm{C}$. The absolute maximum temperature is $+43^{\circ} \mathrm{C}$, the absolute minimum is $-38^{\circ} \mathrm{C}$.

Methods: Stationary sample plots with an area of four $\mathrm{m}^{2}$ were used in six-fold repetition on the sites with a share of the studied species of over $90 \%$ in 2003. The initial data on the content levels of nitrogen and carbon were obtained in 2003-2004. In 2014, we assessed the changes, which had occurred over a ten-year period. Observations, records, and preparation activities were arranged as follows: We took substrate samples using a sampler from the $0-20 \mathrm{~cm}$ horizon at 10 points on the registered site in the following three months: April, July, and October. Mixed samples of soils and sub-soils were taken from each of the six plots for three options. After the preparation of mixed samples, the soil was brought to the air-dried condition. By using the method of round-cell sieve sifting $d=1 \mathrm{~mm}$, fine-grained soil (mechanical substrate separates of $<1 \mathrm{~mm}$ in size) and the skeletal part (separates $>1 \mathrm{~mm}$ ) were isolated. The fine-grained soil and the skeletal part were ground down and analysed separately. The repetition for the determination of all biological indicators is 2-fold and the total one is 12 -fold. For each fraction, we determined the following: total carbon according to A. Ansteta as modified by V.V. Ponomareva and T.A. Nikolaeva, easily hydrolysable nitrogen according to Cornfield, total nitrogen - according to Kjeldahl, and nitrate nitrogen - using the ionometric technique (Arinushkina 1970). To determine substrates nitrification capacity, the samples were composted in a thermostat for 7 days with the soil moisture of $60 \%$ and at a temperature of $28{ }^{\circ} \mathrm{C}$.

\section{RESULTS AND DISCUSSION}

The regional distribution of the studied species is related to incomplete replacement of the past flora, which was widespread in Eurasia by current zonal communities. Three species ( $M$. fragrans Bunge, $H$. cretaceus Dubjan, A. koso-poljanskii Ovcz.) are limited to landscapes with extra-zonal conditions and represent an obsolete element since they do not belong to the current zonal type of the regional flora. These species are listed in the Red Book of the Russian Federation (Red book... 2008).

$M$. fragrans Bunge (Brassicaceae) species. This redivive is a rare type of cretaceous outcrops. A pioneer species appearing on an exposed carbonate substrate. $H$. cretaceus Dubjan (Lamiaceae) species. This half-shrub is an obligate calcicolous plant and an endemic species of the cretaceous outcrops in the southern part of the Russian plain. A pioneer species, which inhabits the cretaceous substrate immediately after exposure. It belongs to upland xerophytes. It forms specific communities - cretaceous hyssop crops, where it acts as an edificatory. The associations have a protective cover of 15-25\%.

A. koso-poljanskii Ovcz (Primulaceae) species. This is an herbaceous polycarpous and endemic plant with large loose tussocks from dense basal rosettes of the Central Russian Upland. It belongs to the Alpine mountain flora, which was formed in the glacial era. It is distributed on soils with well-defined soil horizons, with the number of substrate particles $<1 \mathrm{~mm}$ in size of more than $60 \%$. The projective cover of the species can reach maximum $70-90 \%$.Due to the active manifestation of soil erosion, these species move across various relief features as the dominants of the communities.The main biological processes of substrate changing under the studied species develop in two main directions:

1. In the rhizosphere of $M$. fragrans Bunge and $H$. cretaceus Dubjan species, which have a core root system, the basic soil formation processes actively develop in chalk cracks, where particles of $<1 \mathrm{~mm}$ in size are accumulated. Accumulation of plant residue and root secretions, their humification, and nitrogen and carbon accumulation occur around the root systems to the depth of their penetration. 2. Local soil formation under A. koso-poljanskii Ovcz. It belongs to Alpine meadow polsters by type, when the biological pedogenesis processes occur on the soil surface. A substrate, which form polsters inside, mainly consists of dead leaves decomposing on the soil surface.In comparison with the environment, the stable in-chalk temperature conditions contribute to high biological activity within the root system 
distribution area. As part of the vital plant processes, the rhizosphere accumulates amino acids, sugars, and high molecular and slightly degradable organic matter residues in the form of fiber, lignin, etc. There are changes occurring in the soil physical properties. First of all, the proportion of small particles and gravel in the substrate changes.

It has been established that over a 10 -year period the number of particles of $<1 \mathrm{~mm}$ in size is significantly increases under $M$. fragrans Bunge, $H$. cretaceus Dubjan. During the 10-year period, their proportion has increased by 186.6 and $131.4 \%$ in relative terms respectively (Table 1). No significant differences were detected in the fraction of small particles under $A$. kosopoljanskii Ovcz. Communities with the predominant $A$. koso-poljanskii mainly occupy the upper part of the slope on the dense substrates that have already undergone pedogenesis processes largely (low stone crushing degree, well-formed soil water-bearing structure, and well-defined soil horizons). The physical properties of the soil remain relatively stable.

The involvement of organic matter in the mineral substrate is accompanied by increased substrate biological activity in the rhizosphere due to microorganisms, which are included in the nitrogen transformation cycles. There are two parallel on-going processes observed: increasing the number of fine particles in the substrate and changes

Table 1. Change in the proportion in substrate particles of $<1 \mathrm{~mm}(\%)$ in size under individual of calciphilous species

\begin{tabular}{|l|l|l|}
\multirow{2}{*}{ Plant species } & \multicolumn{2}{|l|}{ Year of research } \\
\cline { 2 - 3 } & 2004 & 2014 \\
\hline Matthiola fragrans Bunge & $11.2 \pm 0.6$ & $32,1 \pm 1.6$ \\
\hline Hyssopus cretaceus Dubjan. & $12.4 \pm 0.6$ & $28.7 \pm 1.8$ \\
\hline Andorsace koso-poljanskii Ovcz. & $64.1 \pm 3.7$ & $65.7 \pm 2.4$ \\
\hline
\end{tabular}

in the content of nitrogen of related different forms.The accumulation of total nitrogen $\left(\mathrm{N}_{\text {total }}\right)$ and total carbon $\left(\mathrm{C}_{\text {total }}\right)$ and their ratio $\left(\mathrm{C}_{\text {total }}: \mathrm{N}_{\text {total }}\right)$ are the most important indicators of the overall direction of nitrogen status dynamics processes. The most significant changes in the content of $\mathrm{N}_{\text {total }}, \mathrm{C}_{\text {total }}$ occurred under the pioneering species of $M$. fragrans Bunge, $H$. cretaceus Dubjan which initially populate carbonate substrates. As compared to the initial state, a significant increase in carbon and nitrogen was reported both in small and large particles. The $\mathrm{C}_{\text {total }}$ content in the particles $<1 \mathrm{~mm}$ increased by $27-31 \%$, and in particles of $>1 \mathrm{~mm}$ in size by $16-17 \%$. The number $\mathrm{N}_{\text {to- }}$ respectively $40-50 \%$ in particles of $<1 \mathrm{~mm}$ in size and $32-34 \%$ particles of $>1 \mathrm{~mm}$ in size. No significant difference between the total nitrogen and the total carbon was found in the particles of $<1 \mathrm{~mm}$ in size under $A$. kosopoljanskii Ovcz., but it was found that these elements had increased in the skeletal part (Table 2).

The $\mathrm{C}_{\text {total }}$ and $\mathrm{N}_{\text {total }}$ content in the substrate dominated by $A$. koso-poljanskii Ovcz. is much higher than their content in the substrate under the other two calciphilous species. The ratio of their content in the substrate particles of $<1 \mathrm{~mm}$ in size and particles of $>1 \mathrm{~mm}$ in size is very narrow and it is within 1.3-1.4. This can be explained by the washing action of water coming from the surface. Because of this process, a water-soluble (fulvic acids) part of the plant polster humus enters the deeper horizons and is absorbed by the skeletal part of the chalk as a porous structure and it is accumulated in the upper part of the soil. The same consistent pattern is evident for the total nitrogen. As a result, the substrate becomes more homogeneous with respect to the chemical properties as compared to the substrate under $M$. fragrans Bunge, $H$. cretaceus Dubjan.

The $\mathrm{C}_{\text {total }}: \mathrm{N}_{\text {total }}$ ratio in the substrate particles of $<1$ $\mathrm{mm}$ in size and particles of $>1 \mathrm{~mm}$ in size under $A$.

\begin{tabular}{|c|c|c|c|c|c|c|}
\hline \multirow[t]{2}{*}{ Plant species } & \multicolumn{2}{|c|}{$\begin{array}{l}\text { Content Ctotal in the } \\
\text { substrate, } \%\end{array}$} & \multicolumn{2}{|c|}{$\begin{array}{l}\text { Content Ntotal in the } \\
\text { substrate, } \%\end{array}$} & \multicolumn{2}{|c|}{$\begin{array}{l}\text { Ratio Ctotal: } \\
\text { Ntotal }\end{array}$} \\
\hline & 1 & 2 & 1 & 2 & 1 & 2 \\
\hline \multicolumn{7}{|l|}{ Mechanical elements $<1 \mathrm{~mm}$} \\
\hline Matthiola fragrans Bunge & $0.950 \pm 0.062$ & $1.207 \pm 0.024$ & $0.133 \pm 0.006$ & $0.186 \pm 0.009$ & $7.2 \pm 0.2$ & $6.5 \pm 0.4$ \\
\hline Hyssopus cretaceus Dubjan. & $1.092 \pm 0.071$ & $1.434 \pm 0.035$ & $0.144 \pm 0.008$ & $0.220 \pm 0.014$ & $7.6 \pm 0.9$ & $6.6 \pm 0.3$ \\
\hline Andorsace roso-poljanskii Ovcz. & $3.754 \pm 0.169$ & $4.018 \pm 0.204$ & $0.444 \pm 0.018$ & $0.454 \pm 0.013$ & $8.5 \pm 0.5$ & $8.9 \pm 0.1$ \\
\hline \multicolumn{7}{|l|}{ Mechanical elements $>1 \mathrm{~mm}$} \\
\hline Matthiola fragrans Bunge & $0.214 \pm 0.005$ & $0.249 \pm 0.010$ & $0.064 \pm 0.005$ & $0.085 \pm 0.008$ & $3.4 \pm 0.3$ & $3.0 \pm 0.1$ \\
\hline Hyssopus cretaceus Dubjan. & $0.054 \pm 0.002$ & $0.063 \pm 0.008$ & $0.049_{ \pm} 0.013$ & $0.066 \pm 0.003$ & $1.2 \pm 0.3$ & $1.0 \pm 0.1$ \\
\hline Andorsace roso-poljanskii Ovcz. & $2.764+0.193$ & $3.580 \pm 0.181$ & $0.337 \pm 0.025$ & $0.352 \pm 0.020$ & $8.3+0.9$ & $10.2 \pm 0.6$ \\
\hline
\end{tabular}


Table 3. The change in the content of easily hydrolyzed nitrate nitrogen and the nitrification capacity in individual mechanical elements of soil under the local populations of calciphilous species of plants for 10 years

\begin{tabular}{|c|c|c|c|c|c|c|}
\hline \multirow[t]{2}{*}{ Plant species } & \multicolumn{2}{|c|}{$\begin{array}{l}\text { Content } \mathrm{N} \text { 1.g. in the } \\
\text { substrate, } \mathrm{mg} \mathrm{kg}^{-1}\end{array}$} & \multicolumn{2}{|c|}{$\begin{array}{l}\text { Content } \mathrm{N}-\mathrm{NO}_{3} \text { in the } \\
\text { substrate, } \mathrm{mg} \mathrm{kg}^{-1}\end{array}$} & \multicolumn{2}{|c|}{$\begin{array}{l}\text { Nitrification capacity, } \\
\mathrm{mg} \mathrm{kg}^{-1}\end{array}$} \\
\hline & 1 & 2 & 1 & 2 & 1 & 2 \\
\hline \multicolumn{7}{|l|}{ Mechanical elements $<1 \mathrm{~mm}$} \\
\hline Matthiola fragrans Bunge & $57.4 \pm 3.9$ & $90.0 \pm 3.9$ & $12.9 \pm 0.7$ & $17.3 \pm 1.2$ & $15.4 \pm 1.0$ & $20.9 \pm 1.3$ \\
\hline Hyssopus cretaceus Dubjan. & $63.9 \pm 2.3$ & $78.2 \pm 2.2$ & $5.6 \pm 0.5$ & $8.6 \pm 0.4$ & $8.6 \pm 0.6$ & $11.2 \pm 1.1$ \\
\hline Andorsace koso-poljanskii Ovcz. & $226.8 \pm$ & $227.8 \pm 6.1$ & $8.0 \pm 0.6$ & $8.3 \pm 0.2$ & $17.6 \pm 0.6$ & $19.2 \pm 0.4$ \\
\hline \multicolumn{7}{|l|}{ Mechanical elements $>1 \mathrm{~mm}$} \\
\hline Matthiola fragrans Bunge & $7.3 \pm 0.8$ & $12.2 \pm 0.8$ & $6.2 \pm 0.2$ & $9.8 \pm 0.6$ & $3.4 \pm 0.3$ & $12.5 \pm 0.3$ \\
\hline Hyssopus cretaceus Dubjan. & $4.4 \pm 0.4$ & $8.1 \pm 0.4$ & $2.7 \pm 0.9$ & $5.1 \pm 0.2$ & $0.4 \pm 0.1$ & $5.6 \pm 0.7$ \\
\hline Andorsace koso-poljanskii Ovcz. & $224.7 \pm 5.1$ & $223.6 \pm 5.1$ & $4.5 \pm 0.3$ & $4.6 \pm 0.4$ & $15.5 \pm 0.5$ & $17.0 \pm 0.2$ \\
\hline
\end{tabular}

koso-poljanskii Ovcz. was not significantly different from each other and it was within 8.3-8.5 in 2003-2004 and $8.9-10.6$ in 2014. Under the other species, this ratio was significantly lower, especially particles of $>1 \mathrm{~mm}$ in size, which may indicate that there was a more intensive organic, matter mineralization process in the rhizosphere of the pioneer $M$. fragrans Bunge, $H$. cretaceus Dubjan. as compared to A. koso-poljanskii Ovcz.

It is known that the plant growth and development is more dependent on the content of available forms of soil nitrogen rather than on its total reserves (Arinushkina, 1970). Easily hydrolysable nitrogen is a potential reserve for ground accumulation of the most important forms of soil nitrogen - nitrate and ammonium. The growth rate of roots and the content of related auxins in the plants, which receive nitrogen in the form of nitrates, are higher.Table 3 contains data on the accumulation dynamics for easily hydrolysable and nitrate nitrogen in the soil under certain types of calciphilous species and on changes in nitrification capacity for 10 years of the experiment. We established a positive accumulation dynamics for the easily hydrolysable nitrogen and nitrate nitrogen under species, which develop at the early stages of cretaceous outcrops overgrowing, both in substrate particles of $<1 \mathrm{~mm}$ in size and in a larger fraction of $>$ $1 \mathrm{~mm}$ in size. These processes run most effectively under $M$. fragrans Bunge, $H$. cretaceus Dubjan. The content of $\mathrm{N}$ l.g. in substrate particles of $<1 \mathrm{~mm}$ in size increased for 10 years by $22-56 \%$, with the highest intensity being under $M$. fragrans Bunge, and the accumulation under $H$. cretaceus Dubjan was $67-84 \%$ more intense in the substrate particles of $>1 \mathrm{~mm}$ in size. No statistically significant trend was established for the accumulation of $\mathrm{N} 1 . \mathrm{g}$. over a 10-year period under A. koso-poljanskii Ovcz.The content of easily hydrolysable nitrogen was consistently high under A. koso-poljanskii Ovcz. both in substrate particles of $<1 \mathrm{~mm}$ in size, and in particles of $>1 \mathrm{~mm}$ in size and had no significant differences.A trend similar to easily hydrolysable nitrogen was established for the content of nitrate nitrogen. Accumulation of nitrates both in substrate particles of $<1 \mathrm{~mm}$ in size and in a larger fraction of $>1 \mathrm{~mm}$ in size for 10 years was more significant under $M$. fragrans Bunge and $H$. cretaceus Dubjan. and made up to 34-52\%. In particles of $>1 \mathrm{~mm}$ in size, the increase under these two species was $25-34 \%$. The content of A. koso-poljanskii Ovcz. nitrates was close, and no mathematically proven dynamics was established for a 10-year period.

A change in the nitrification activity is an indirect indicator of the biological activity dynamics. It has increased under the pioneering species over a 10-year period by 1.3 times in particles of $<1 \mathrm{~mm}$ in size under $M$. fragrans Bunge, $H$. cretaceus Dubjan. Particles of $>$ $1 \mathrm{~mm}$ in size showed differences that are more significant. If the substrate nitrification activity under $M$. fragrans Bunge is increased 3.6 times, it will become 13.8 times higher under $H$. cretaceus Dubjan, which indicates to a sharp increase both in biological activity and in intensity of substrate destruction by root systems. The substrate nitrification capacity under $A$. koso-poljanskii Ovcz. was steadily high.The results of the assessments of the nitrate content in the substrate and its nitrification capacity give important findings on higher biological activity of the pioneer species, which develop in the early stages of carbonate substrate overgrowth as compared to species participating in successions later.

\section{CONCLUSION}

The endemic species of Matthiola fragrans Bunge and Hyssopus cretaceus Dubjan, which inhabit cretaceous outcrops the southern of the Central Russian Upland in 
the early self-growth stages, actively change the substrate towards increasing the content of total nitrogen, total carbon, and easily hydrolysable nitrogen. These species increase the biological activity of both substrate fine part (particles of $<1 \mathrm{~mm}$ in size) and the skeletal part (particles of $>1 \mathrm{~mm}$ in size). The nitrification capacity of the skeletal part of the substrate (particles of $>1 \mathrm{~mm}$ in size) under pioneering species $M$. fragrans Bunge and $H$. cretaceus Dubjan becomes higher with increasing the related fractions of $<1 \mathrm{~mm}$ in size, which can be diagnosed using average strength correlation $(r=0.634 \pm 0.121)$. However, a similar trend was not identified ( $\mathrm{r}=0.234 \pm 0.321$ ) under Andorsace koso-poljanskii Ovcz. growing on a fresh chalk substrate for 10 years. The experiment results have showed that there is a negative correlation $(r=0.463 \pm 0.234)$ between the substrate carbon accumulation and the substrate nitrate content. We have found that $A$. koso-poljanskii Ovcz. can have a preserving effect on the substrate, which becomes obvious through its more stable nitrification capacity in time. It has been diagnosed using a wider ratio of the total carbon to the total nitrogen both in particles of $<1$ $\mathrm{mm}$ in size $\left(\mathrm{C}_{\text {total }}: \mathrm{N}_{\text {total }}=8.5 \pm 0.5 \div 8.9 \pm 0.1\right)$, and in particles of $>1 \mathrm{~mm}$ in size $\left(\mathrm{C}_{\text {total }}: \mathrm{N}_{\text {total }}=8.3 \pm 0.9 \div 10.2 \pm 0.6\right)$.

\section{REFERENCES}

Abe, T., Tanaka, N. and Shimizu, Y. (2018). Plant species diversity, community structure and invasion status in insular primary forests on the Sekimon uplifted limestone (Ogasawara Islands). J Plant Res, 131(6): 1001-1014. https://doi. org/10.1007/s10265-018-1062-5.

Abramova, T.I. (1973). Vegetation of cretaceous outcrops Don River basin's steppe part within the Rostov and Volgograd regions. Botanical J, 5 (4): 562-570.

Altay, V., Karahan, F., Öztürk, M., Hakeem, K.R., Ilhan, E. and Erayman, M. (2016). Molecular and ecological investigations on the wild populations of Glycyrrhiza L. taxa distributed in the East Mediterranean Area of Turkey. J Plant Res, 129(6): $1021-1032$.

Arinushkina, E.V. (1970). Guide on the Chemical Analysis of Soils. Moscow State University Publishing, Moscow.

Baskauf, C.J. and Burke, J.M. (2009). Population genetics of Astragalus bibullatus (Fabaceae) using AFLPs. J Heredity, 100(4): 424-431. https://doi.org/10.1093/jhered/esp033.

Cowling, R.M. and Hilton-Taylor, C. (1994). Patterns of plant diversity and endemism in South Africa: An overview. In: Botanical Diversity in Southern Africa. Pp 31-52 (Ed) B.J. Huntley, National Botanical Research Institute.

Degtyar, O.V. and Chernyavskih, V.I. (2006). The environmentforming role of endemic species in calciphilous communities of the southern Central Russian Upland. Russ J Ecol, 37(2): 143-145. https://doi.org/10.1134/S1067413606020135.
Dorofeeva, L.V., Starodumova, I.P., Krauzova, V.I., Prisyazhnaya, N.V., Vinokurova, N.G., Lysanskaya, V.Y., Tarlachkov, S.V. and Evtushenko L.I. (2018). Rathayibacter oskolensis sp. nov., a novel actinobacterium from Androsace koso-poljanskii. Ovcz. (Primulaceae) endemic to the Central Russian Upland. Intern $J$ of Systematic and Evolutionaty Microbiol, 68(5): 1442-1447. https://doi.org/10.1099/ijsem.0.002681.

Dumacheva, E.V., Cherniavskih, V.I., Markova, E.I., Klimova, T.B. and Vishnevskaya, E.V. (2015). Spatial pattern and age range of cenopopulations Medicago L. in the conditions of gullying of the southern part of the Central Russian Upland. Res J Pharm Biol Che, 6(6): 1425-1429.

Golitsyn, S.V. (1956). To the flora of the easting wing of the Upper Pooskolie. Botanical J, 41(10): 1428-1438.

Gorbunov, A.S. and Bykovskaya, O.P. (2012). Issues on optimizing the ecological situation and vertical differentiation of landscapes of the forest-steppe zone of the chalk south of Central Russian upland. Arid Ecosystems, 2(2): 9197.

Gusev, A.V., Zolotukhin, N.I. and Reshetnikova, N.M. (2017). Materials for the second edition of the Red Book of the Belgorod region. The plants, lichens, fungi and animals that are recommended for inclusion into the lists of protected species. 2. Section vascular plants. Nauch. Ved. Belgorod. Gos. Univ., Ser. Estestv. Nauki., 38(4): 16-38.

Khadeeva, N.V., Goriunova, S.V., Kochumova, A.A., Iakovleva, E.Iu., Mel'nikova, N.V., Zholobova, O.O., Korotkov, O.I. and Kudriavtsev, A.M. (2011). Genetic monitoring of populations of Matthiola fragrans (Bunge) using RAPD and AFLP analysis. Biol Bull, 38(4): 389-396.

Kurkina, Y.N., Huong, N.T.-L., Batlutskaya, I.V. and Lazarev, A.V. (2015). Micromycetes of some legume crops' rhizosphere. Res J Pharm Biol Che, 6(6): 1681-1685.

Lisetskii, F.N. (1992). Periodization of antropogenically determined evolution of steppe ecosystems. Sov J Ecol, 23(5): 281287.

Lisetskii, F.N. (2007). Interannual variation in productivity of steppe pastures as related to climatic changes. Rus J Ecol, 38(5): 311-316.

Lisetskii, F.N. (2012). Soil reproduction in steppe ecosystems of different ages. Contemp Prob1 Ecol, 5(6): 580-588. https://doi. org/10.1134/S1995425512060108

Lisetskii, F.N., Sudnik-Wojcikowska B.,and Moysiyenko I. I. (2016). Flora differentiation among local ecotopes in the transzonal study of forest-steppe and steppe mounds. Biol Bull, 43(2): 169-176. https://doi.org/10.1134/S1062359016010106

Lousley, J.E. (1969). Wild Flowers of Chalk and Limestone. Collins, London, 254.

Maschinski, J., Baggs, J.E. and Sacchi, Ch.F. (2004). Seedling recruitment and survival of an endangered limestone endemic in its natural habitat and experimental reintroduction sites. American J Botany, 91(5): 689-98. https://doi.org/10.3732/ ajb.91.5.689. 
Neuendorf, K.K.E., Mehl Jr., J.P. and Jackson, J.A. (2005). Glossary of Geology (5th ed.). Alexandria (VA): American Geological Institute, 779. ISBN 0-922152-76-4.

Red Book of the Russian Federation (plants and mushrooms) (2008). Association of scientific publications KMK, Moscow, 855. ISBN 958-5-87317-476-8.

Robinson, J. and Hermanutz, L. (2015). Evaluating human-disturbed habitats for recovery planning of endangered plants. J Environ Manag, 150: 157-163. https://doi.org/10.1016/j.jenvman.2014.10.033.

Rodríguez-Celma, J., Lattanzio, G., Villarroya, D., GutierrezCarbonell, E., Ceballos-Laita, L., Rencoret, J., Gutiérrez, A., del Río, J.C., Grusak, M.A., Abadía, A., Abadía, J. and López-
Millán, A.F. (2016). Effects of Fe deficiency on the protein profiles and lignin composition of stem tissues from Medicago truncatula in absence or presence of calcium carbonate. J Proteomics, 140: 1-12. https://doi.org/10.1016/j.jprot.2016. 03.017 .

Scholle, P.A., Bebout, D.G. and Moore, C.H. (1983). Carbonate Depositional Environments. Memoir 33. American Association of Petroleum Geologists, Tulsa, Oklahoma, 708. ISBN 978-089181-310-1.

Ukrainskij, P.A., Terekhin, E.A. and Pavlyuk, Ya.V. (2017). Fragmentation of forests in the upper part of the Vorskla River basin since the end of the 18th century. Vestnik Moskovskogo Universiteta, 5(1): 82-91. 